\title{
Yaratıcı Drama Alanında Peter Slade'in Drama Anlayışının İncelenmesi
}

\author{
İstek Aksak Kömür ${ }^{1}$
}

Ali Öztürk²

$\ddot{O}_{z e t}$

Bu çalı̧̧ma, yaratıcı drama alanında Peter Slade'in drama anlayışını incelemek amacıyla gerçekleştirilmiştir. Araştırmada nitel araştırma deseni kullanılmıştır. Verilerin toplanması doküman incelemesi tekniğiyle, verilerin çözümlenmesi betimsel analizle yapılmıştır. Araştırmada Slade 'in yaşam öyküsü ve drama anlayışı; ilkeleri, amaçlarl, oyun ve özellikleri, katılımcı özellikleri, öğretmen özellikleri, mekan ve kullanılan materyaller ve dramayı ele alış biçimi temaları altında incelenmiştir.

Bu araştırmada elde edilen bulgular; Peter Slade'in, bireyin mutlu ve dengeli olmasını amaçlayan bir drama anlayışı modeli ortaya koyduğu, bu modelde dramanın temelinin oyun olduğu belirlenmis ve bireyin ancak oyun oynayarak mutlu ve dengeli olabileceği vurgulanmıştır.

Anahtar Sözcükler: Peter Slade, çocuklarla drama, yaratıcı drama

\section{Investigation Of Peter Slade's Apprehension Of Drama In The Field Of Creative Drama}

\begin{abstract}
This study was aimed to investigate Peter Slade's apprehension of drama in the field of creative drama. In the study qualitative research design was used, data was gathered in the technique of document analysis and analyzed using descriptive analyses. Slade's biography, principles, gerneral aims, characteristics of play, participants, teachers, place and materials used and how he handles drama were examined.

The findings of this study shows that Peter Slade's drama apprehension based on plays which aimed the happiness and balance of individuals and individuals could only achieve to be happy and balanced by playing.

Key Words: Child drama, creative drama, Peter Slade

\section{Giriş}

İngiltere'de dramanın gelişimiyle ilgili ilk adımlar sırasıyla; Harriet Finlay-Johnson, Caldwell Cook ve ardından Peter Slade tarafından atılmıştır (Bolton, 1999; Sağlam, 2004; Carkin, 2007; Adıgüzel, 2010). Dramanın gelişimine ilişkin ilk yazılı eserler Finlay-Johnson, Cook ve Peter Slade’e aittir. Cook, “Oyun Yolu” (Play Way) adlı kitabını 1917'de yayınladıktan sonra bu alanda otuz yedi yıl boyunca yazılı bir esere rastlanmamaktadır. 1954 yılında Peter Slade'in yazdığı "Çocuklarla Drama" (Child Drama) adlı kitapla drama, yeniden tartışılmaya başlamıştır. Yaratıcı drama tarihine Peter Slade büyük katkı sağlamış, çocuklarla dramanın ilk uygulayıcılarından olmuştur.
\end{abstract}

Bilim Uzmanı, M.E.B, e-posta: istekaksak@yahoo.com

2 Doç. Dr., Anadolu Üniversitesi Eğitim Fakültesi, e-posta: alio@anadolu.edu.tr 
Slade, yaşamının büyük bölümünü bu alanda yaptığı çalışmalara adamıştır. Slade'in etkisi, yaratıcı drama kuram ve uygulayıcılarının çalışmalarında açıkça görülmektedir. Örneğin Drama Yoluyla Gelişim (Development Through Drama) adlı kitabın yazarı ve drama alanında yaptığı çalışmalarla tanınan Brian Way, Peter Slade ile tanışma ve onunla çalışma şansını yakalamıştır. Way, Slade'in Child Drama (Çocuklarla Drama) adlı kitabının editörlüğünü yapmış, onu temsilen bazı drama çalışmalarına liderlik etmiştir (Slade, 1968). Dorothy Heathcote 1966-1968 y1llarında Slade'den etkilendiği için farklı ülkelerin hastanelerini ziyaret ederek orada bulunan bedensel ve zihinsel engelli insanlarla drama çalışmaları yapmıştır (Casson, 1997, s.10). Bolton (1999), Slade'in drama anlayışını kavrayabilmek için onun öncülüğünü yaptığı düşünceleri ve uygulamalarını bilmek gerektiğini ifade etmiştir. Çocuklarla drama çalışmalarının ilk temel kuramsal yapısını bilmek, günümüzde çocuklarla drama çalışmalarının daha iyi anlaşılmasına da yardımcı olacaktır. Bu çalışmanın, yapılan ilk çalışmalar arasında olmasından dolayı bundan sonra yapılacak olan araştırmalara katkı sağlayabileceği ve kuramsal bilgiye gereksinimi karşılayacağı düşünülmektedir.

\section{Yöntem}

\section{Araştırmanın Deseni}

Araştırmada nitel araştırma desenlerinden durum çalışması (case study) kullanılmış ve durum olarak Peter Slade'in drama anlayışı incelenmiştir. "Nitel araştırma, gözlem, görüşme ve doküman incelemesi gibi nitel veri toplama yöntemlerinin kullanıldı̆̆ı, algıların ve olayların doğal ortamda gerçekçi ve bütüncül bir biçimde ortaya konmasına yönelik nitel bir sürecin izlendiği araştırma olarak tanımlanabilir" (Glaser, 1978'den akt. Y1ldırım ve Şimşek, 2011, s. 39). Yin'e göre durum çalışmasının tanımı "Güncel bir olgu, durum ve gruplar üzerine odaklanan, derinlemesine incelemedir” (Yin, 1994, s.3). Bir başka tanımda ise çalışılacak durumlara "Bir birey, bir kurum, bir grup, bir ortam örnek oluşturabilir" (Yıldırım ve Şimşek, 2011, s.77).

\section{Veri Toplama Araçları}

$\mathrm{Bu}$ araştırmada verilerin toplanması, "Doküman incelemesi” tekniğiyle yapılmıştır. "Doküman incelemesi, araştırılması hedeflenen olgu veya olgular hakkında bilgi içeren yazılı materyallerin analizini kapsar. Nitel araştırmada doküman incelemesi tek başına bir veri toplama yöntemi olabileceği gibi diğer veri toplama yöntemleri ile birlikte de kullanılabilir" (Yıldırım ve Şimşek, 2011, s.187). Veriler, Peter Slade'in kendi yazdığı kitaplar ve ulaşılabilen makalelerden toplanmıştır. Verilerin toplanmasında Peter Slade'in kendi yazdığ 1 kitaplar; Çocuklarla Drama -Child Drama- (1969), Doğal Dans - Natural Dance - (1977), Spontanlık DeneyimiExperience of Spontaneity- (1968), Çocuklarla Dramaya Giriş- Introduction to Child Drama- (1976), Çocuk Oyunu: İnsan Gelişimi İçin Önemi- Child Play: The Importance of Human Development - (1995), kitapçıklar; Dans-Dance - (1979), St. Patrick (tarihsiz), Herkes İçin Bir Şans- A Chance For Everyone - (1969) ve makaleler kullanılmıştır.

\section{Verilerin Analizi ve Yorumlanması}

$\mathrm{Bu}$ araştırmada elde edilen veriler, araştırmanın amacına göre betimsel analiz ile incelenmiştir. Betimsel analizde, “... elde edilen veriler, daha önceden belirlenen temalara göre özetlenir ve yorumlanır” ( Yıldırım ve Şimşek, 2011, s.224). Bu çalışmada araştırma sorularından yola çıkarak veri analizi için bir çerçeve oluşturulmuş, veri için elde edilen kaynaklar orijinal dilde okunarak araştırmacı tarafından Türkçeye çevrilmiş, araştırmacı tarafından temalar oluşturulmuş, veriler içinde araştırmacı tarafından temalar aranmış, veriler belirlenen temalar çerçevesinde bir araya getirilmiş ve elde edilen bulgular yorumlanarak raporlaştırılmıştır. 
Bu araştırmada temalar; Peter Slade'in yaşam öyküsü, drama anlayışında; genel ilkeler, genel amaçlar, oyun ve özellikleri, katılımcı özellikleri, öğretmen özellikleri, mekân ve kullanılan materyaller, dramayı ele alış biçimi olarak belirlenmiştir.

\section{Bulgular}

\section{Peter Slade'in Yaşam Öyküsü}

Peter Slade, 1912'de İngiltere'de Fleet, Hampshire'da doğmuştur. Slade, varlıklı bir ailenin ikinci çocuğuydu. Ailesi, disipline ve çocuklarının kendilerine ve ülkelerine karşı sorumlulukları olduğuna inanıyorlardı. Slade ve kendisinden üç yaş büyük abisine küçükken bakıcılar ve dadılar bakmıştır. Slade, okula başlamadığ yıllarda çoğunlukla Birinci Dünya Savaşı ile ilgili dramatik oyunlar oynadığını yazmıştır (Slade, 1968, s.12). 1918 yılında, Slade altı yaşındayken tüberküloz hastalığına yakalanmıştır. Sonradan bu hastalık konuşmasını da etkilemiştir. Henüz yedi yaşındayken ailesi Slade’i yatılı bir okula göndermiştir.

Slade, 1924 yılında ilkokuldan mezun olmuş ve ardından ortaokula başlamıştır. Slade, daha on yedi yaşındayken dramatik-atletik-hareket kuramını tamamlamıştır (Jackson, 2012, s.153). Dramaya kuramsal bir yaklaşım olan bu çalışma, Slade'in kendi ve arkadaşlarının etkinliklerinin gözlemlerine dayanır (Maulitz, 1971, s. 7).

Slade 1930 yılında kendilerini Çayır Oyuncuları (Fen Players) diye adlandıran ve yetişkin aktörlerin rol aldığı bir tiyatro kurumunda çalışmıştı. Coggin'in aktardığına göre Slade bu yıllarda henüz on altı yaşlarındaydı ve yetişkin tiyatrosunu yönetiyordu. Maulitz'e göre bu çalışma muhtemelen dramatik-atletik-hareket kuramının gelişimine yardım etti (Coggin, 1956, s.263. akt. Maulitz, 1971, s.8).

Slade’i ailesi Almanya'ya göndermişti. Burada Almanca, ekonomi ve felsefe okudu (Jackson, 2012; Dodds, 2004). Farklı meslek gruplarından insanlarla tanıştı. Almanya'da Jungçu bir psikoterapist olan William Kraemer ile tanıştı. Daha sonra birlikte çalıştılar. 1931 yılında Almanya'dan İngiltere'ye geri döndüğünde aktör eğitimi veren bir drama [tiyatro] okulunda eğitim almıştır (Maulitz, 1981, s. 10). Ardından 1935'te ilk tiyatro okulunu açarak gezici tiyatro için oyuncu eğitmeye başlamıştır.

1936 yılında Birmingham'da BBC radyosunda "Çocukların Saati” programını yaparken radyonun en genç amcası seçilmiştir. Slade, radyo programından sonra çocuklarla bir araya gelip düşünce oyununa (Ideas game) dayalı doğaçlama çalışmaları yapmıştır. Çocuk oyunları ve draması hakkında gözlemler yapmaya başlamıştır. Slade radyoda çalıştı̆̆ zamanlarda görme problemi yaşamaya başlamıştır. Bundan dolayı bu işinden ayrılmak zorunda kalmıştır (Slade, 1968, s.83).

Slade, 1936'da Parable Players'i (Eğitici Hikaye Oyuncuları) kurmuş okullara ve kiliselere giderek oyunlar oynamışlardır. Slade, profesyonel oyuncu gruplarını eğitmeye başlamıştır. Bu sırada babasını kaybeden Slade, Londra' da bulunan eğitim stüdyosundan vazgeçmiştir. Maddi olarak çok zor zamanlar geçiren Slade, boş zamanlarında sokakta oynayan çocukları gözlemlemiş; yaratıcı oyuna nasıl daldıklarını, birdenbire koşmaya başladıklarını ve bundan aldıkları zevki fark etmiştir. Bu gözlemler sonucunda Slade, "çocuk draması" (Çocuklarla drama) felsefesinin temellerini atmıştır.

1937-1939 yılları arasında Londra'da sürgünde olan Jungçu psikoterapist Dr. W. Kramer ile birlikte çalışarak dramayı terapide kullanmıştır. 1939'da Peter Slade İngiliz Tıp Derneği'nde (British Medical Association) drama terapi hakkında konferans vermiştir. Bu konuda kendisiyle yapılan bir röportajda "1938 yılında dramaterapi (tek sözcük olması önemli) olarak kullanan ve hakkında 1938-39 yıllarında İngiliz Tıp Derneği’nde ilk konuşan kişiydim”(Slade ile söyleşi, 1999, s.254) demiştir. Aynı yıl Slade, Worcestershire'da bulunan Tenbury Wells’te 
sanat merkezini açmıştır. Burada başarısız ve mutsuz çocuklara yardım etmek için kendi drama yöntemini kullanmıştır. 1941'de bir eğitim filmi çekerken bir kaza geçirmiş, uzun süre hastanede kalmıştır. İyileşir iyileşmez hastalarla tiyatro oyunu provalarına başlamıştır. 22 Aralık 1941'de J.M. Barrie'nin oyunu "Sevgili Brutus"u iki kez sahnelemişlerdir. Hastane çalışanları onun çalışmasını destekleyerek kendisine değer vermiştir.

1942 yılında iyileştikten sonra İngiltere'nin Staffordshire şehri Eğitim Komitesi'nde drama danışmanı olarak çalışmaya başlamıştır. 1942 yılında Slade Dr. Wilhelm Viola'nın Çocuk Sanatı (Child Art) adlı kitabındaki düşüncelerden haberdar olmuştur. Çocuk sanatı ve dramayla paralellik olabileceğini ve bunu bir gün bir kitapta yazması gerektiğini düşünmüştür (Slade, 1968; 1969).

Slade birçok farklı gruplarla çalışma olanağı bulmuştur. "The Pear Tree Players’1 (Armut Ağacı Oyuncuları)" kurmuştur. Armut Ağacı Oyuncuları 1945 yılında dramayı okullara ve gençlik kulüplerine taşıyan ilk profesyonel kurum olmuştur (Slade, 1968, s.193). Slade, 1948 yılında günümüzde faaliyette olmayan Eğitsel Drama Derneği’nin (Educational Drama Association) yöneticisi olmuştur. Eğitsel Drama Derneği tarafından yayınlanan günümüzde yayınlanmayan "Yaratıcı Drama- Creative Drama" dergisinin de editörü olmuştur. Ardından Peter Slade, İngiltere'nin Birmingham Eğitim Komitesi'nin (Birmingham Education Committee) ilk drama danışmanı olarak 1947 yılında bu göreve getirilmiş ve bu görevinden 1977 yılında ayrılmıştır (Jackson, 2012, s.154 ). Slade bu görevini otuz yıl sürdürmüştür. Slade bu görevindeyken drama alanında uzman öğretmenlerin yetiştirilmesi konusunda da eğitimler vermeye ve bu konuda rehberlik etmeye başlamıştır.

Slade, psikodramanın yaratıcısı J.L. Moreno ile 1938'den beri yazışmıştır. Moreno İngiltere’yi 19481951 arasında ziyaret etmiş ve Slade ile görüşmüştür.

Slade, dramayı okullara taşımış ve eğitim fakültelerinde drama eğitimini geliştirmek için çalışmalar yapmıştır. Slade, sokak çocuklarıyla da çalışmalar yapmıştır. Bunun sonucunda bir proje geliştirmiştir. Birçok çocuğun geldiği doğaçlamaların yapıldığı Pete'nin Mutfağı (Pete’s Kitchen) adlı yeri açmıştır.

İngiltere'de yerel yetkililerin destekleriyle Rea Sokağı Merkezi'ni (the Rea Street Center) kurmuş ve burada çocuklar için drama çalışmaları düzenlemiştir. Yetişkin oyuncular tarafindan oynanan çocuk oyunları yaratmış ve öğretmenlere dramayla ilgili kurslar vermiştir. Sylvia Demmery ile birlikte 1968'de "Doğal Dans"1 (Natural Dance) yaratmıştır. Doğal Dans, Slade'in ilk gözlemlerine ve atletik hareketlere dayanıyordu (athletic movement). Endüstride çalışan ve satış elemanı olarak görev yapan yetişkinler için kişilik eğitimi geliştirmiştir. On üç yıl suçlu ve engelli kişilerle özel çalışmalar yürütmüştür. Açtığı yaz okulunda, dünyanın dört bir yanından gelen öğretmenleri eğitmiştir. 1954'te “Çocuklarla Drama”(Child Drama) adlı kitabını yayınlamasıyla uluslararası bir ün kazanmıştır. 1964 yılında Londra’da düzenlenen ilk Uluslararası Çocuk Tiyatrosu Konferansı'nda yaratıcı drama bölümüne başkanlık etmiştir.

Hornbrook, Slade'in “Rousseau'nun romantik doğalcı akımının estetik anlayışını miras olarak aldığını” ifade etmiştir (Hornbrook, 1998, s.10). Sağlam (2004)'a göre Slade "Çocuk Draması adında kendi başına bir sanat biçimi olduğunu ilk söyleyen eğitimcidir”. San, Slade için“1954'lerde Finlay-Johnson'ın 'make believe play’ine doğallık boyutunu katarak kendiliğindenlik (spontaneity) ögesinin ve bugün kullandığımız anlamda doğaçlama tekniğinin de işin içine girmesine önayak” olduğunu belirtmiştir (San, 2002, s.63).

Slade, emekliliğinde Krallık Sanat Topluluğunun üyesi olmuştur ve 1997'de “Kraliçe Ellinci Yıl Gümüş Madalyası” almıştır.1997'de Manchester Üniversitesi Slade'i eğitsel dramanın gelişimine yaptığı katkılardan ötürü onursal üye ilan etmiştir. 1997'de İngiliz Dramaterapistler Birliği (British Association of Dramatherapists) onun çalışma yaşamını bir konferans düzenleyerek kutlamıştır.

Slade, 28 Haziran 2004 tarihinde vefat etmiştir. 


\section{Peter Slade'in Drama Anlayışı}

\subsection{Genel ilkeler}

a. Oyun, tiyatro değildir: Bu ilke "Drama, tiyatro değildir.” şeklinde de yorumlanabilir. Çünkü Slade, dramanın temelini oyuna dayandırmaktadır. Ona göre yetişkin, özellikle çocukları düşünerek tiyatro ve drama arasındaki ayrımı dikkatli bir biçimde yapmalıdır. Yetişkin, çocuğun yaptığı dramayı tiyatro ile karıştırmamalıdır. Slade, tiyatro ve dramanın ayrımını şöyle ifade etmiştir: Drama tiyatro değildir.Tiyatroda oyuncu ve seyirci varken dramada herkes etkinliğin içerisindedir. Dramada hem seyirci hem de oyuncu olmak mümkündür. Deneyimler heyecan verici ve kişiseldir. Deneyimler grup içinde gelişir.

b. Kişisel Oyun ve Tasarlanan Oyun: Slade, oyunu ikiye ayırmıştır; kişisel oyun ve tasarlanan oyun. Kişisel oyunda insan bedenini kullanır. Tasarlanan oyunda ise insan tam anlamıyla zihnini kullanılır fakat bedenini çok kullanmaz (Slade, 1969, s.29). Tasarlanan oyunda değerli nesneler kullanılır. Değerli nesnelerle kastedilen; oyuncak bebekler, legolar, eski kağıtlar vb. Slade, kişisel ve tasarlanan oyun biçiminin birbirini desteklediğini, oynayan kişiye nitelikler kazandırdığını ve bu niteliklerin bireyin büyümesinde önemli olduğunu savunmuştur.

c. Tekrarlayan Şekiller: Slade, çocuklarla dramada doğal olarak ortaya çıkan ve tekrarlayan şekillerin olduğunu savunarak, ortaya çıkan bu şekillerin bütün çocuklarda ortak olduğunu belirtmiştir. Görülen en sık ve etkili şekil ise çemberdir. Slade, çok erken yaşlarda bebeklikten itibaren çocuğun yaşamında çemberin sürekli olarak tekrarlandığını ve gelişmesine yardım edilirse dansa dönüşebileceğini, çember ve çeşitlemelerinin yaş gruplarına göre farklılıklar gösterdiğini belirtmiştir.

d. Sanat (Tasarlanan Oyun) ve Drama Arasındaki İlişki: Slade, çocukların koşarken oluşturduğu S, yıldız ya da üçgen şekillerinin çocuğun çizimlerinde de ortaya çıktığını belirtmiştir. O, sanat ve drama arasındaki ilişkiyi şu örnekle açıklamıştır:

Çocuklar koşarken birbirlerine çarpabilir. Çarpışmanın sona erdiği noktada resimsel kompozisyon da gelişmeye başlar. Dramayla çocuklar üç boyutu deneyimleyerek kütle ve alan arasındaki farkı ayırmaya başlarlar (kişisel oyunları). Çünkü bedenlerini, hızlarını ve kendileri ile diğer kişiler arasındaki farkları görürler. Dramada yapılan uygulamalar sayesinde çarpışma daha erken sonlanır. Beraberinde sanat da gelişir. Sonuçta kişinin gelişiminde sanat önemli bir ölçme aracıdır (Slade, 1976, s.8-9).

\subsection{Genel Amaçlar}

Slade; insanın, çocuklarla dramada mutluluğu ve sağlığı bulduğunu belirterek, çocukların yaptığı dramanın amacına verilebilecek en kısa yanıtı "mutlu ve dengeli birey olma” olarak vurgulamıştır (Slade, 1969, s.105). Ona göre drama yoluyla kazanılan amaçlar şunlardır: Sevgi ve nefret hazinelerin (treasures) kullanımıyla giderilebilir. (Hazineler çocuğun sevdiği nesneler yani oyuncakları olarak ifade edilebilir). Çocuk oyuncaklarını sevdiği kadar onlardan nefret edebilir ve bu duyguların boşalımı için onları kullanabilir. Drama yoluyla çocuk sürekli deneyimler ve eğlenceli maceralar yaşar. Yaşamı yaparak yaşayarak deneyimleyen çocuğun kendine olan güveni artar. Dramada yapılan uygulamalar dil gelişimine katkı sağlar. Çocuğun kişisel becerileri gelişir. Arkadaşlık ve güven bağı oluşur. Çocukların bir araya gelerek oluşturdukları grup ve içlerinde taşıdıklarl şiddetli duygularını açığa çıkarmaları için drama onlara yasal bir zemin oluşturur. Kurgusal bir dünya olduğu için çocuk gerçek yaşamdaki gibi düşs kırıklı̆̆ına uğramadığı için oyuna karşı bă̆lılı̆̆ gelişir. Dramada denemelerin ve tekrarların olması, belleğin ve zihnin gelişime katkı sağlar. Duygusal eğitim ve estetik karşılaşmayla manevi deneyimler oluşur. Kişisel tecrübelerle inanç kuvvetlenir. Verilen yönergelere uyma ögrenilir. Drama çocuğun 
gerçekten kim olduğunu ve kendisini keşfetmesini sağlar. Arkadaşlarıyla iyi iliş̧kiler kurmasına yardımcı olur. Kelimelerde, harekette, nesnelerde ve giysilerde tutumluluğun gelişmesi olanaklıdır. Hayal gücünü geliştirir. Dramayla çocuğun görgüsü gelişir. İleriki yaşlarda zevk için çıkış noktası olan dansa karşı hevesi artar. Erdem ve yiğitlik (grace and virility) duygusu gelişir. Çocuk her yaşta yavaş yavaş iyi davranış için ahlaki sorumluluk alır. Olası sonraki yaşantıları için önceden tecrübe eder ve sorunlarla baş edebilmeyi ögrenir. Bu güçlükler çocuğa, kararlılık ve bilgelik kazandırır. İçtenlik gelişir. Değerlerin gelişimini sağlar. Yazma gelişir. Resim yapmaya yardımcı olur. Daha kolay odaklanmayı sağlar (Slade, 1969, s.105-122; 1995, s. 168-170) .

Slade, bu amaçlara bir de dramatik değerleri eklemiştir. Dramatik değerler; dramada kazandırılması istenen değerler, dramada grubun devamını sürdürmek için çocuklar tarafindan doğru kabul edilen ortak amaçlar olarak açıklanabilir (Slade, 1954;1995, s.169).

\subsection{Oyun ve Özellikleri}

Slade'e göre "Oyun doğuştan gelir ve çocuğun yaşamında önemli bir yere sahiptir. Oyun, boşu boşuna yapılan bir etkinlik değildir. Çünkü oyun yoluyla çocuk düşünür, deneyim kazanır, dinlenir, çalışır, hatırlar, cesaretlenir, dener, yaratır ve odaklanır" (Slade, 1976, s.1)

“...Oyun eksikliği, birinin daima kayıp bir tarafi anlamına gelebilir. Bu bilinmeyen birinin yaratılmayan yanı, eksik bağlantı, sonraki yıllarda belirsizlik ve zorluk olarak ortaya çıkabilir” (Slade, 1976, s.5).

Oyun, gerçek yaşamın kendisidir. En iyi çocuk oyunu; sadece fırsat ve cesaretin, yetişkin tarafından bilinçli olarak verildiği yerde olur. Bu bir büyütme, bakma sürecidir. Arkadaşlıkla, çocukta güven oluşturmak, sempatik düşünceyle de doğru ortamı oluşturmak gerekir (Slade, 1976, s.1).

"Yaşamın bize verdiği büyük hediyelerden biri, oynamasını bilmektir. Gençken, çoğumuz bunu nasıl yapacağımızı biliriz. Yaşlandıkça neşemiz kaçar ve gerçeklik denen sıkıcı şey yaşamımıza girer” (Slade, 1995,s.2).

\subsection{Katılımcı Özellikleri}

Slade, dramanın çok erken başladığını savunmuş ve gözlemine bebeklerden başlamıştır. Gözlemleri sonucunda Slade, dramayı doğal gelişim basamaklarına ayırmıştır (Slade, 1969, s.128). Bu durum, kuram ve uygulayıcılar içinde ilk olma özelliği taşımaktadır. Doğal drama gelişim basamakları; 0-5, 5-7, 7-12, 12-15 yaş biçimindedir. Bu basamaklara göre drama bebeklikten itibaren başlamaktadır. Çocuklar doğdukları andan itibaren kendi sanatını, dramasını doğal olarak oluşturur. Bebeklikle başlayan dramanın okul sürecinde de öğretmenlerin rehberliğinde büyütülmesi ve beslenmesi gerekmektedir.

\section{5. Öğretmenin Özellikleri}

Peter Slade (1996, s.83)'e göre öğretmen, “Sevgi dolu bir işbirlikçidir (ally).” Öğretmen; öğrencilere ne yapacağını öneren ve öğrenciler ihtiyaç duyduğunda öğrencilere beceriler kazandıran kişidir. Öğretmen, çocuğun oyununa müdahalede bulunmaz. “Öğretmen çocuğa nasıl hareket etmesini göstermeli mi?” diye sorulduğunda Slade şöyle cevaplamıştır: "Ĕger gösterirse bu drama değildir. Eğer çocuk hayal etme konusunda başarısızsa ne yapacağı konusunda birkaç öneride bulunabilir ama nasıl yapması konusunda değil.” diyerek öğretmenin sorumluluklarını belirtmiştir. Ayrıca Slade, dramanın doğal gelişim basamaklarına göre öğretmenlere ayrı ayrı önerilerde bulunmuştur. 


\subsection{Mekân ve Kullanılan Materyaller}

Slade, okul öncesi yaş grubu için paylaşımın önemli olduğunu vurgulayarak dramatik oyun için doğru mekânın salon veya sınıf olduğunu ve özellikle oyunun zeminde, yerde olması gerektiğini savunmuştur. Çünkü en iyi oyun burada oynanır (Slade, 1969, s.44). İlköğretim çağı için mekânı sınıf ya da salon olarak belirlemiş ve zeminde, yerde olmasını vurgulamıştır. Eğer sınıf sıralarla doluysa sıraları kaydırıp ortada daha geniş bir alan oluşturulabilir. Ortaöğretim çağı çocuklar için oyunun yerde oynanmasının teşvik edilmesi gerektiğini vurgulamıştır. Eğer salonda bir sahne varsa perdeleri kapalı tutulabilir ya da arka alan oyunu (hinterland) oynatılabilir. Bu oyunda gizliliği korumak için oyun kapalı bir yerde oynanır. Örneğin, sınıfta bir sahne varsa perdeler çekilir ve perdenin arkasında oyun oynanır veya oyun masanın altında devam eder. Eğer büyük yaş grubu sahneyi sorarsa o zaman “....perdeleri aç ve kullanmaları için izin ver. Biz istediğimiz için değil artık onlar istiyorlar" (Slade, 1976, s.58).

Slade, çocuklarla dramada kullanılan mekânın fiziksel özelliklerinin yanında ortamın da önemli olduğunu vurgulamıştır. Yaptığı okul ziyaretlerinin birinde çocuk dramasının ilkelerini kabul eden ve çalışmalarının tamamını bu ilkelere göre yapan okulu "mutlu bir okul" olarak nitelemiştir. Slade'e göre okul, mutlu bir yer olmalidir (Slade, 1969, s.205).

Kullanılan materyaller arasında müzik özellikle küçük yaş grupları için ön planda tutulmuştur. Slade, müziğin çocuk için yardımcı olduğunu, ruh halini değiştirdiğini, ortamı olumlu hale dönüştürdüğünü ve zirveye ulaşmasına yardımcı olduğunu belirtir. Aynı zamanda çocuğa nasıl hareket edebileceği konusunda kibarca öneri de verir (Slade, 1969, s.251). Kullanılan materyaller arasında; davul, müzikçalar, piyano, gong, eski teneke kutular, zımpara kağıdı, baget yer almıştır.

Slade'in mekân kullanımı hakkındaki bazı görüşleri şu şekildedir: "Yükselti, tasarlanan oyunda kullanılır. Tuğlalar zemini seviye seviye ve yavaş yavaş yükseltmek için kullanılabilir." (1976, s.45), "En iyi çalışma, en az giysi kullanıldığında yapılır." (Slade, 1995, s.43). "Gerçek çocuklarla drama iç yaratıma dayanır, dış materyalizme değil.” (Slade,1969, s.338). Bununla beraber Slade, kostüm ve maske kullanımını tamamen kaldırmamıştır. Maske ve kostümlerin çocuklar tarafından üretilmesini önermiştir. Özellikle yarım maskeler göz ve ağız kısmını kapatmayan biçimde olmalıdır. Maske, utangaç çocuklar için iyi olabilir. Fakat çok sıcak olacağından dolayı, burnu açık maskeler tercih edilmelidir (Slade, 1969, s.340). Makyaj kullanımına az da olsa izin verilmesini önerir. Ancak çocuklar tarafından yapılmalıdır. Çünkü makyaj çocukların sanatıdır.

\subsection{Dramayı Ele Alış Biçimi}

Dramayı ilkokulda tarih, coğrafya ve din dersi gibi kabul etmenin mümkün olduğunu vurgulayarak, dramanın da bir disiplin olması gerektiğini belirtmiştir (Slade, 1969, s.150). Slade, çocuklarla dramayı iyileştirici terapatik bir araç olarak da görmüştür (Slade, 1969; 1995). Slade, drama ve terapi olarak yazılan iki ayrı sözcüğü ilk defa İngilizcede bitişik "dramaterapi” olarak kullanan ilk kişidir.

\section{Sonuç ve Öneriler}

\section{Sonuç}

Slade'in drama anlayışının genel ilkelerinde, genel amaçlarında, oyun ve özelliklerinde, katılımcı özelliklerinde, öğretmen özelliklerinde, mekân ve kullandığı materyaller ile dramayı ele alış biçiminde Slade'in kendi yaşam öyküsü etkili olmuştur. 
Peter Slade'in drama anlayışının amacı bireyin mutlu ve dengeli olmasını sağlamaktır. Bunu başarmanın da en doğal yolu oyundur. Slade anaokulunda oyun oynayan çocukların üst sınıflara gittiğinde de oyun oynamalarının devamının gerekliliğini belirtmiştir.

Slade, dramayı bir disiplin olarak ele almıştır. Slade, sürecin önemini vurgulayarak katılımcı odaklı çalışmalar yapmıştır. Çocuklarla dramanın tiyatroyla karıştırılmaması gerektiğini vurgulamıştır.

Slade, dramada kullanılan materyallerin yaratımları engellememesi gerektiğini, abartılı materyal kullanımının yaratımların önüne geçeceğini, materyal kullanım zorunluluğu var ise materyallerin de çocuklar tarafından üretilmesi gerektiğini savunmuştur. Müzik kullanımının drama çalışmalarında önemli olduğunu vurgulamıştır.

Slade, dramatik oyunun anaokulunda, ilköğretim ve hatta ortaöğretim çağı çocuklarında zeminde ve yerde olması gerektiğini savunmuştur. Drama çalışmaları için özel bir mekân belirlemenin aksine, kalabalık ve sıralarla dolu sınıflarda yapılan drama çalışmaları için öğretmenlere önerilerde bulunmuştur. Ortaöğretim yaş grubunda ise sahne sorulduğunda kullanmaları için izin verilmesi gerektiğini ifade etmiştir. Slade, çocuğun özellikle erken yaşta sahne ile tanışmaması için gerekli bütün tedbirlerin alınmasını savunur. Ona göre, çocuğun erken yaşta daha önce hiç deneyimlemediği sahneyle tanışması dramada olması gereken iki niteliğin; odaklanma ve içtenliğin ölmesi anlamına gelir.

Slade, çocuklarla dramada doğal olarak ortaya çıkan ve tekrarlayan şekillerin olduğunu savunarak, ortaya çıkan bu şekillerin bütün çocuklarda ortak olduğunu belirtmiştir. Görülen en sık ve etkili biçim ise çemberdir

Slade, sanat ve drama arasında bir ilişki kurmuştur. Çocuğun sanatsal gelişimi ile çocuklarla dramada doğal olarak ortaya çıkan, tekrarlayan şekiller arasında yakın bir ilişki olduğunu savunmuştur.

Slade, çocuklarla dramada oyunu; tasarlanan oyun ve kişisel oyun olmak üzere ikiye ayırmıştır. Her iki oyun türü de dramadır. Odaklanma ve içtenlik çocuklarla dramada önemli iki niteliktir. Dolayısla bu niteliklerin ölmemesi için büyük çabanın gösterilmesi gerektiğini belirtmiştir.

Slade, düşünce oyunu (ideas game) olarak adlandırdığı bir başka oyunu, kendisinin bulduğunu iddia etmiştir. Düşünce oyunuyla dramaya ve doğaçlamaya başlamanın daha kolay olduğunu, oyununun çocukları işbirliğine davet ettiğini, doğaçlanacak hikayenin çocuklarla birlikte oluşturulduğunu bu yüzden paylaş1lan ortak yaratımda çocukların katılıma daha hevesli olduklarını savunmuştur.

Slade, dramayı doğal gelişim basamaklarına ayırmıştır. Bu durum kuram ve uygulayıcılar içinde ilk olma özelliği taşımaktadır. Doğal drama gelişim basamakları; 0-5, 5-7, 7-12, 12-15 yaş biçimindedir. Bu basamaklara göre drama bebeklikten itibaren başlamaktadır. Çocuklar doğdukları andan itibaren kendi sanatını, dramasını doğal olarak oluşturur. Bebeklikle başlayan dramanın okul sürecinde de öğretmenlerin rehberliğinde büyütülmesi beslenmesi gerekmektedir.

Slade, drama ve terapi olarak yazılan iki ayrı sözcüğü ilk defa İngilizcede bitişik “dramaterapi” olarak kullanan ilk kişidir. Slade, çocuklarla dramayı terapatik yani iyileştirici bir araç olarak görmüştür. Drama sayesinde, gelişim dönemindeki normal bir çocuğun, karşılaştığı psikolojik sorunların üstesinden kolaylıkla gelebileceğini iddia ederek, dramanın terapi amaçlı kullanılabileceğini yaptığı uygulamalarla savunmuştur. 


\section{Öneriler}

Araştırma bulgularından yola çıkarak aşağıdaki öneriler yapılabilir:

1. Türkiye'de yaratıcı drama alanında eğitim veren kurum ve kuruluşların öğretim programlarında Peter Slade'in drama uygulamalarına yer verilebilir. Peter Slade'in drama üzerine yazdığı kitaplar ve yaptığ drama atölyeleri uygulama örnekleriyle detaylı bir şekilde incelenebilir.

2. Peter Slade'e göre çocuğun gelişimiyle paralellik gösteren dramanın doğal gelişim basamakları, gelişim psikolojisi odaklı olarak incelenebilir.

3. Peter Slade'in "dramada çember” kavramı, günümüzdeki drama anlayışlarıyla karşılaştırılarak yeni araştırmalar desenlenebilir.

\section{Kaynakça}

Adıgüzel, Ö. (2010). Eğitimde yaratıcı drama. Ankara: Naturel Yayınevi.

Bolton, G.(1999). Acting in classroom drama: A critical analysis. Birmingham: University of Central England.

Carkin, G. (2007). Teaching English through drama: The State of the Art. Manchester: Carlisle Publication.

Casson, J. (1997). Dramatherapy history in headlines: Who did what, when, where? Dramatherapy. Dramatherapy, 19:2, www.tandfonline.com/loi/rdrt20 adresinden 10-13.30 Mart 2013 tarihinde edinilmiştir.

Cook, H. C. (1917). The play way. London: William Heinemann. (reprinted 1966).

Dodds, H. (2004). Peter Slade the first British dramatherapist. England: The Guardian.

Hornbrook, D. (1998). Education and dramatic art. Routledge: London and New York.

Jackson, A. (2012). Mapping the archieves 1.Research in Drama in Education:The Journal of Applied Theatre and Performance [Elektronik versiyon] London:Routledge 26 May1s 20123 tarihindehttp://www.tandfonline.com/loi/crde20 edinilmiştir.

Maulitz, S.R. (1971). The contribution of Peter Slade to child drama in England. Yayınlanmamış Yüksek Lisans Tezi, Georgia University, Athens.

Sağlam, T. (2004). Dramatik eğitim: Amaç mı? Araç mı? Ankara Üniversitesi Dil ve Tarih-Coğrafya Fakültesi Tiyatro Bölümü Tiyatro Araştırmaları Dergisi s.17(s.4-21).

San, İ. (2002). Yaratıcı drama- eğitsel boyutları. Adıgüzel, H.Ö. (Ed.), Prof. Dr. İnci San'a armağan yaratıcı drama 19851995 yazilar. Ankara: Naturel Yayınlar

Slade, P. (tarihsiz). St. Patrick. London: Educational Drama Associaton.

Slade, P. (1968). Experience of spontaneity. London and Harlow: Longmans.

Slade, P. (1969). Child drama. London: Hodder and Stroughton.

Slade, P.(1969). A chance for everyone. Cassell \&Company Ltd.

Slade, P. (1976). An introduction to child drama. London: Hodder and Stroughton.

Slade, P. (1977). Natural dance. London: Hoder and Stoughton.

Slade, P.(1979). Dance. London: Educational Drama Associaton.

Slade, P. (1995). Child play: Its importance for human development. London: Jessica Kingsley.

Slade, P.(1998). The importance of dramatic play in education and theraphy. Child Psychology\&Psychiatry Review Volume 3, No.3. (Elektronik versiyon)

Slade, P. (1999). Peter Slade talks. Research in drama education: The journal of applied theatre and performance [Elektronik versiyon] 4:2, 253-257 19 Ocak 2012 tarihinde www.tandofline indirimiştir.

Yıldırım, A. ve Şimsek, H.(2011). Sosyal bilimlerde nitel arastırma yöntemleri. Ankara: Seçkin.

Yin, R. (1994). Case Study Research: Design and Methods, California: Sage 